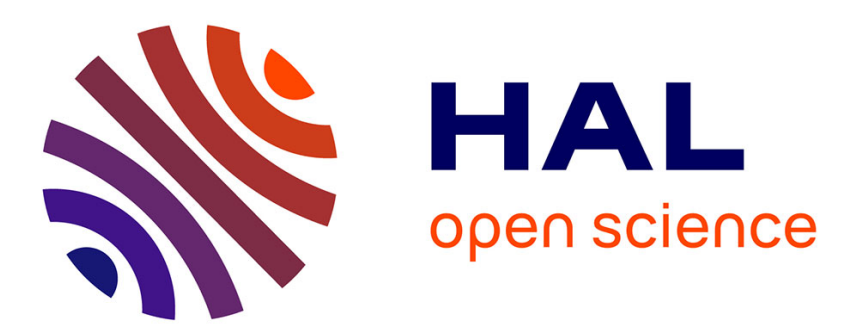

\title{
Marked population increase in Pale-headed Brush-finch in response to cowbird control
}

\author{
Niels Krabbe, Mery Juiña, Aldo Fernando Sornoza
}

\section{To cite this version:}

Niels Krabbe, Mery Juiña, Aldo Fernando Sornoza. Marked population increase in Pale-headed Brushfinch in response to cowbird control. Journal für Ornithologie $=$ Journal of Ornithology, 2010, 152 (2), pp.219-222. 10.1007/s10336-010-0567-z . hal-00614848

\section{HAL Id: hal-00614848 \\ https://hal.science/hal-00614848}

Submitted on 17 Aug 2011

HAL is a multi-disciplinary open access archive for the deposit and dissemination of scientific research documents, whether they are published or not. The documents may come from teaching and research institutions in France or abroad, or from public or private research centers.
L'archive ouverte pluridisciplinaire HAL, est destinée au dépôt et à la diffusion de documents scientifiques de niveau recherche, publiés ou non, émanant des établissements d'enseignement et de recherche français ou étrangers, des laboratoires publics ou privés. 
NIELS KRABBE, MERY JUIÑA and ALDO FERNANDO SORNOZA

\title{
Marked population increase of Pale-headed Brush-finch Atlapetes pallidiceps in response to cowbird control
}

\begin{abstract}
The Pale-headed Brush-Finch Atlapetes pallidiceps is an emberizine finch confined to south-central Ecuador and critically endangered owing to cowbird parasitism and habitat loss. We report a marked increase in numbers of brush-finches after seven years of cowbird control, confirming that brood parasitism had been an important limiting factor, and that shooting with firearms can be an effective method of controlling local cowbird parasitism.
\end{abstract}

\section{Keywords}

Ecuador · Atlapetes pallidiceps $\cdot$ Critically endangered $\cdot$ population status $\cdot$ Cowbird control

\section{Zusammenfassung}

Deutlicher Populationsanstieg der Blasskopf-Buschammer Atlapetes pallidiceps als Antwort auf die Bestandsregulierung von Kuhstärlingen

Die Blasskopf-Buschammer Atlapetes pallidiceps ist eine Ammer, die nur in Südzentralecuador vorkommt und durch Kuhstärlings-Parasitismus und Habitatverlust vom Aussterben bedroht ist. Wir berichten von einer deutlichen Zunahme der Buschammernzahl nach siebenjähriger Bestandsregulierung von Kuhstärlingen und bestätigen somit, dass Brutparasitismus ein wichtiger limitierender Faktor gewesen war und das Schießen von Kuhstärlingen mit Schusswaffen eine effektive Methode sein kann, Kuhstärlings-Parasitismus lokal zu kontrollieren.

Niels Krabbe 
Zoological Museum, University of Copenhagen, Universitetsparken 15, DK-2100, Copenhagen, Denmark

e-mail: nkkrabbe@snm.ku.dk

\section{Juiña $\cdot$ A. F. Sornoza}

Fundación Jocotoco, Avenida de Los Shyris 37-146 y El Comercio, Quito, Ecuador. 


\section{Introduction}

Atlapetes pallidiceps was feared extinct for over two decades, when the discovery of a small population in the upper Yunguilla Valley in 1998 raised hope for its future survival (Agreda et al. 1999). A reserve to protect it was established by Fundación Jocotoco in 1999 with the purchase of 27 ha of land. Over subsequent years adjacent lots were added to the reserve, and by 2009 the reserve encompassed 150 hectares holding $94 \%$ of all known territories of A. pallidiceps. A study in 2002 found that parasitism by Shiny Cowbird Molothrus bonariensis seriously affected its breeding success, with nine of fifteen nests (61\%) parasitized (Oppel et al. 2003, 2004). Cowbird control by shooting was initiated in 2003. The present paper presents the number and turnover rate of territorial brush-finch males counted annually from 1999 to 2009 and examines trends in relation to cowbird control.

\section{Methods}

The number of territorial males was monitored annually by NK from 1999 to 2009. This was done during the first two weeks of March, when vocal activity was most pronounced, except for 1999 - 2001, when the time of breeding had not yet been established and when counts were made on 23-26 February and 1-20 May (1999), 14-20 April (2000), and 5-12 Feb and 16-27 March (2001). Additional brief visits were also made during the dry season 1998-2001, in June, August, September, November and December. MJ spent several weeks in the reserve during much of the rainy season in 2002 (30 March-30 April), 2003 (3 March-28 May), 2004 (15 Feb-15 May), 2005 (15 Feb-15 May), 2006 (1 Feb-30 April), 2007 (7-12 March and 6-7 April) and 2008 (10-16 March), searching for nests, ringing nestlings, and studying the behaviour of the species through careful observation.

Singing males were tape-recorded whenever possible. Playback of the species' song or duet was used in order to obtain more tape-recordings and to determine if individuals had been ringed with colour bands. Playback sometimes provoked birds from adjacent territories to vocalize, which aided in delimiting territories. The location of singing males was determined and mapped with a GPS. Males had unique song qualities that when first developed, varied little from year to year (Krabbe 2004), so double registration was minimized by comparing spectrograms of the songs recorded. Because birds did not sing during heavy rains and only sang consistently during 10-45 minutes after dawn and only for a limited number of days during the breeding season, it was not always possible to record all pairs, so, in addition to the actual count, an estimate was made of the total number of territories believed to be occupied. If the same individual had occupied a territory both the year before and the year after a count, it was counted as also being present there during the year of the count. In areas that could only be visited at times when general vocal activity was low, the number of occupied territories was estimated to be the same as the year before.

The annual turnover of singing males (Fig. 2) was estimated up until 2007 in order to better understand the population dynamics. It was measured for territories where males were tape-recorded on two subsequent years, and was calculated as the number of new males divided by the total number of males in these territories. Birds that had moved from one territory to another were not counted as new. Minimum and maximum values were calculated by ex- or including birds of questionable identity. Turnover was not measured after 2007 when there were too many birds to get sufficiently long taperecordings of each. 
Cowbird control was undertaken by AS, who spent the entire breeding season every year from 2003 onwards (late February to early May) shooting cowbirds (Molothrus bonariensis), preferentially females, as soon as these approached or entered the reserve. Cowbirds collected were sexed, examined for stomach contents, prepared as study skins and deposited in Museo Ecuatoriano de Ciencias Naturales, Quito.

\section{Results}

Number of occupied territories

The annual numbers of territorial males counted and estimated are shown in Fig. 1. Estimates were usually the same as or slightly higher than the number counted. Notable exceptions were 1999, 2000 and 2002, when only half of the breeding grounds were visited, and 2009, when breeding was delayed. The estimates from those years are thus less accurate than for other years, especially 1999 and 2000 when counts were not made during the peak song season.

\section{Cowbird control}

Cowbird control beginning in 2003 virtually removed cowbird parasitism altogether, with only a single nest parasitized in 2003, and one in 2005. Except for the first year, the number of adult cowbirds appearing in the reserve did not diminish significantly over the years (Table 1). Males appeared to outnumber females by a factor of two to four and formed conspicuous displaying groups. Females followed these groups or visited them briefly. Most cowbirds were collected in late February and in March, but a variable proportion (7-27\%) was taken later (latest female collected April 23rd, latest male May 1st). Dark morph females were found to be so similar to males that they could not be safely sexed at a glance in the field.

A steady rise in numbers of occupied brush-finch territories started in 2004, the year after beginning of cowbird control, and continued until the end of the survey in 2009, when the number of territorial males had increased from less than 40 to 113 (Fig. 1).

\section{Turnover}

The annual number of males tape-recorded and number of territories where recordings were made on two subsequent years is given in Table 2. The turnover of singing males 1999-2007 (Fig. 2) averaged 40\%, the same found between 1999 and 2002 (Krabbe 2004 ) but now supported by a larger sample size (156 vs. 40). The smallest turnover measured was $27 \%$, the largest 47-62\%. Once established, males remained in their territory. They were found to have moved to a neighbouring territory on only three occasions $(2 \%)$ and never to a more distant one.

Of sixty-four birds colour ringed as fledglings only six were reliably recorded in subsequent years, in part because many of them had lost one or both colour rings. One of the six was mated and had established a territory when one year old, whereas five were first recorded to have a territory when two years old. At least two of the latter five 
were still in their territory the following year. Some birds gave infrequent, incomplete, weak songs and were presumed to be one-year olds. Such birds were more prone to being overlooked than others. The oldest bird known had a exceptionally distinctive song and was tape-recorded in the same territory every year from 1999 until 2009, by which time it must have been at least 12 years old and was probably older, as it was already pale-headed and had a fully developed song when first recorded.

\section{Discussion}

The apparent increase in brush-finch pairs from 1999 to 2001 (Fig. 1) may have been caused in part by slight improvements of habitat during this time (Krabbe 2004) but are more likely the result of underestimates in 1999 and 2000, when counts were not made during the peak song season. The marked increase in the number of occupied territories after cowbird control was initiated (Fig. 1) on the other hand, is certainly genuine and is evidence that cowbird parasitism had been a major factor in limiting the population size. This is corroborated by the absence of the brush-finch from several patches of seemingly suitable habitat elsewhere in the valley system (Krabbe 2004).

That an increase was discernible after just one year of cowbird control probably indicates that more brush-finches establish territories when only one year old than the few observed colour ringed birds suggests. Early recruitment would also help explain the relatively high turnover rate found.

As evident from figures 1 and 2, the population has not yet reached a saturation point. Based on the observed average territory size of 1 ha and minimum size of 0.5 ha (Krabbe 2004), we expect the population to increase to between 150 and 200 territories, if habitat is managed.

Although shooting of cowbirds has previously been suggested as a feasible method of control (Smith et al. 2000), the efficiency of shooting versus trapping has only been studied recently (Summers et al. 2006a,b). In the upper Yunguilla Valley shooting has proved effective, perhaps in part due to the local topography (all cowbirds coming from the same direction), and partly to the use of a determined and skilled controller. Considering that new cowbirds keep appearing through the breeding season of the brush-finch, and that a single Shiny Cowbird female presumably lays as many as 40 eggs in a season, as known to be the average for the closely related Brown-headed Cowbird (Molothrus ater) (Scott \& Ankney 1980), we suggest that cowbird control in future years continues to cover the peak period of laying from mid February to mid April.

\section{Acknowledgments}

We thank Francisco Sornoza, Enrique Calle, Braulio Carlos, H. Martin Schaefer, Veronica Schmidt, Steffen Oppel, Joan Heathcove, Verónica Ordoñez, Lucas Achig, Rolando Carpio, Rocío Guevara, Dayanara Sanchéz, Harold Greeney, Brett Scheffers and Rudi Gelis, who all contributed to the study; H. Greeney and H. M. Schaefer provided useful comments on the manuscript. The field work was funded by the Jocotoco Foundation and in 2002 and 2003 also by the RSPB and the Sweden Club 300.

\section{References}


Agreda A, Krabbe N, Rodriguez O (1999) Pale-headed Brush-finch Atlapetes pallidiceps is not extinct. Cotinga 11:50-54

Krabbe N (2004) Pale-headed Brush-finch Atlapetes pallidiceps: notes on population size, habitat, vocalizations, feeding, interference competition, and conservation. Bird Conservation International 14:77-86

Oppel S, Schaefer HM, Schmidt V (2003) Description of the nest, eggs, and breeding behavior of the endangered Pale-headed Brush-Finch (Atlapetes pallidiceps) in Ecuador. Wilson Bulletin 115:360-366

Oppel S, Schaefer HM, Schmidt V, Schröder B (2004) Cowbird parasitism of Paleheaded Brush-finch Atlapetes pallidiceps: implications for conservation and management. Bird Conservation International 14:63-75

Scott, DM, Ankney, CD (1980) Fecundity of the Brown-Headed Cowbird in Southern Ontario. The Auk 97:677-683

Smith J NM, Cook TL, Robinson SK, Rothstein SI, Sealy SG (2000) Ecology and Management of Cowbirds and Their Hosts: Studies in the Conservation of North American Passerine Birds. University of Texas Press

Summers SG, Stake MM, Eckrich GH, Kostecke RM, Cimprich DA (2006a) Reducing cowbird parasitism with minimal effort shooting: a pilot study. The Southwestern Naturalist 51:409-411

Summers SG, Kostecke RM, Norman GL (2006b) Efficacy of trapping and shooting in removing breeding brown-headed cowbirds. Wildlife Society Bulletin 34:1107-1112

Table 1. Number of cowbirds killed in the Yunguilla Reserve 2003-2009. Females were shot preferentially, increasingly so in later years, so the numbers do not reflect the natural sex ratios.

\begin{tabular}{cccccccc}
\hline Year & 2003 & 2004 & 2005 & 2006 & 2007 & 2008 & 2009 \\
\hline Females & 22 & 11 & 6 & 6 & 17 & 19 & 10 \\
Males & 47 & 19 & 20 & 12 & 20 & 17 & 13 \\
Both sexes & 69 & 30 & 26 & 18 & 37 & 36 & 23 \\
\hline
\end{tabular}

Table 2. Number of territorial males of Atlapetes pallidiceps tape-recorded 1999-2007 and number of territories where tape-recordings had also been obtained the previous year.

$\begin{array}{llllllllll}\text { Year } & 1999 & 2000 & 2001 & 2002 & 2003 & 2004 & 2005 & 2006 & 2007\end{array}$




\begin{tabular}{cccccccccc}
\hline Males tape-recorded & 12 & 15 & 29 & 16 & 27 & 33 & 37 & 42 & 50 \\
Turnover sample size & & 12 & 13 & 15 & 15 & 23 & 25 & 28 & 28 \\
\hline
\end{tabular}

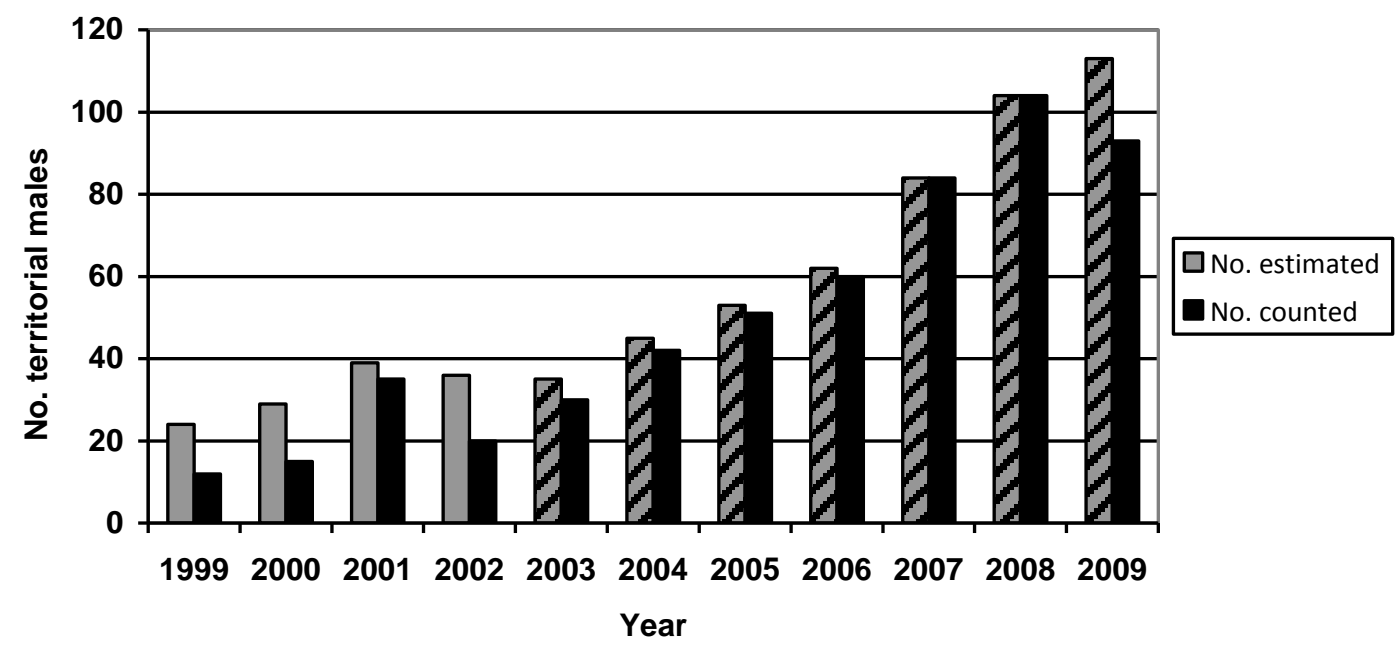

Figure 1. Number of territories occupied by Atlapetes pallidiceps 1999-2009. Slanting lines indicate years with cowbird control. Estimates from 1999 and 2000 are not from peak song season and may be too low.

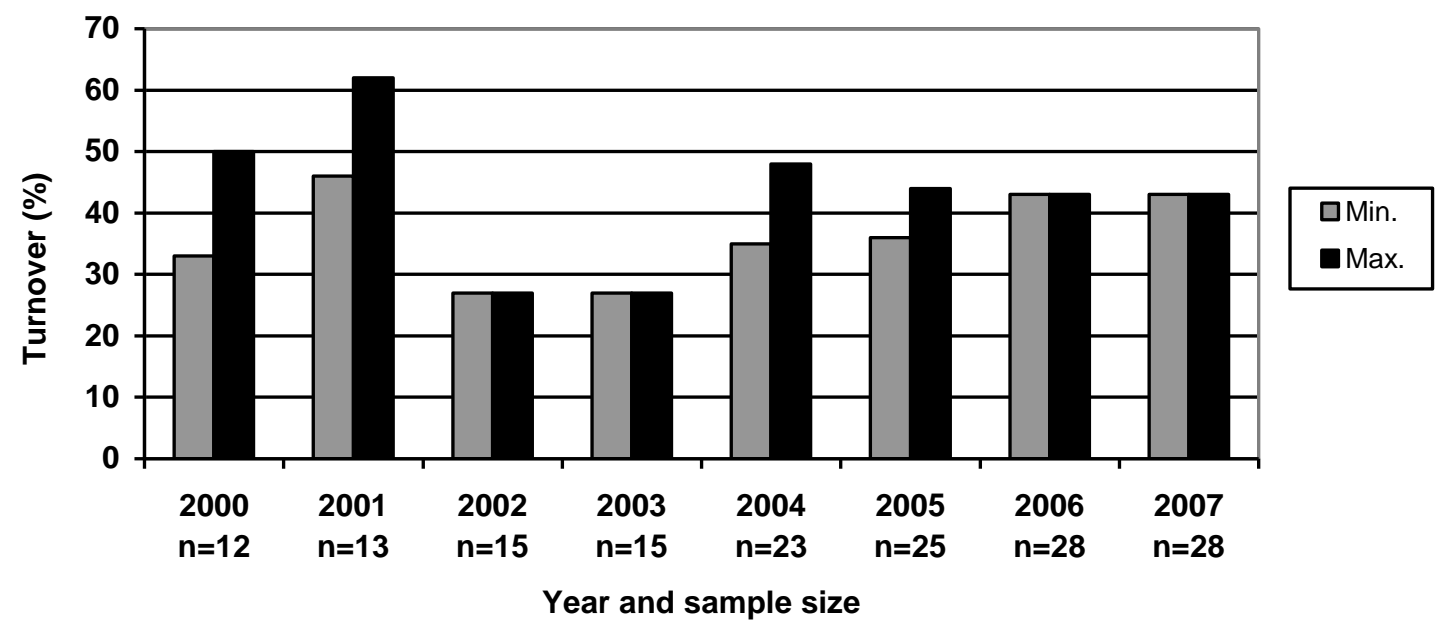

Figure 2. Turnover of territorial males of Atlapetes pallidiceps measured as the number of territories where a new male had replaced the one from the year before, divided by the number of territories where males were tape-recorded both years (n). The turnover was between $27 \%$ and $62 \%$ and averaged $40 \%$. 